Research Article

\title{
Comparative analysis of the efficacy of topical negative pressure dressing with conventional wound dressing in wound healing
}

\author{
Sanjay N. Koppad*, Suresh Badiger, Mallikarjun Desai, Harsha Kodliwadmath
}

Department of General Surgery, SDM College of Medical Sciences, Sattur, Dharwad, Karnataka, India

Received: 01 June 2016

Accepted: 06 June 2016

*Correspondence:

Dr. Sanjay. N. Koppad,

E-mail: sanjaykoppad@gmail.com

Copyright: () the author(s), publisher and licensee Medip Academy. This is an open-access article distributed under the terms of the Creative Commons Attribution Non-Commercial License, which permits unrestricted non-commercial use, distribution, and reproduction in any medium, provided the original work is properly cited.

\section{ABSTRACT}

Background: Wounds and their management are fundamental to the practice of surgery. In the past 15 years there have been significant advances in complex acute and chronic wound management. One of the one of the most significant discoveries was the improvement in wounds with negative pressure-assisted wound closure. In this study, the efficacy of topical negative pressure dressing with that of a control group using conventional moist wound dressings, in healing of wounds, was assessed with quality of wound healing.

Methods: This is a prospective randomized observational study, 50 patients visiting medical college hospital with acute and traumatic wounds, sub-acute wounds, chronic open wounds, of which 25 patients underwent topical negative pressure dressing. The remaining 25 patients underwent conventional moist wound dressings. Wounds were assessed depending on wound size and percentage of reduction of wound size, wound bed score, percentage of granulation tissue cover, graft take up as the percentage of ulcer surface area. Statistical analysis was done using unpaired students $\mathrm{T}$ test and paired $\mathrm{T}$ test. A p-value $<0.05$ was taken as significant.

Results: Our study shows statistically significant reduction in wound size, in the study group 19.52 square centimetres $\left(\mathrm{cm}^{2}\right)$ as compare to control group i.e. $6.64 \mathrm{~cm}^{2}(\mathrm{p}<0.001)$. There is significant increase in wound bed

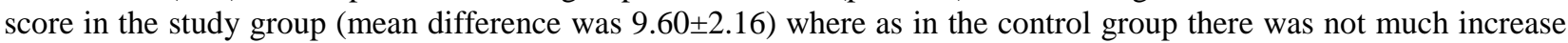
in wound bed score (mean difference was 5.12 \pm 1.99 ) ( $\mathrm{p}$ valve 0.00001). The percentage of granulation tissue formation in the study group was $81.0 \pm 8.29$ and in the control group was $53.60 \pm 19.23$ ( $\mathrm{p}$ value=0.00001). The percentage of graft take up in the study group was $83.42 \pm 4.43$ and in the control group was $63.18 \pm 11.24$ (p value $=0.00001)$. The mean hospital stay and cost of hospital stay is also reduced in topical negative pressure dressing group when compared to conventional wound dressings group.

Conclusions: It is concluded that topical negative pressure dressing is better the conventional wound dressings in wound healing.

Keywords: Topical negative pressure dressing, Wound bed score, Diabetic foot, Ulcer healing

\section{INTRODUCTION}

Wounds and their management are fundamental to the practice of surgery. A wound is a break in the integrity of the skin or tissues often, which may be associated with disruption in the normal anatomical structure and function. ${ }^{1}$ Wound repair is the effort of injured tissues to restore their normal function and structural integrity after injury. During the effort to restore barriers to fluid loss and infection, re-establish normal blood and lymphatic flow patterns, and restore the mechanical integrity of the injured system, often times flawless repair is sacrificed because of the urgency to return to function. ${ }^{2}$ Wound healing is a complex cellular and biochemical cascade that leads to restitution of integrity and function. ${ }^{3}$ The treatment and healing of wounds are some of the oldest subjects discussed in the medical literature. In the past 15 years there have been significant advances in complex 
acute and chronic wound management. One of the most significant discoveries was the improvement in wounds with negative pressure assisted wound closure. With this technology, the surgeon now has additional options besides immediate closure of wounds (i.e. adjunctive therapy before or after surgery or an alternative to surgery in the extremely ill). Clinical benefits of negative pressure therapy have been demonstrated in randomized control trails and case-control studies. These benefits include decrease in wound volume or size, accelerated wound bed preparation, accelerated wound healing, improved rate of graft uptake, decreased drainage time for acute wounds, reduction of complications, enhancement of response to first line treatment, increased patient survival, and decreased cost. Application of a sub atmospheric pressure in a controlled manner to the wound site has got an important role in assisting wound healing. ${ }^{2}$

The objective of the study to compare the efficacy of topical negative pressure dressing with a control group using conventional moist wound dressings, in healing of wounds.

\section{METHODS}

This is a prospective randomized observational study which was conducted in the department of surgery, Rural Medical College Loni, India from December 2011 to October 2013. The source of data was patients admitted as inpatients for the management of wounds. The sample size was 50 cases: 25 patients received topical negative pressure dressing (study group), 25 patients received conventional saline dressings (control group). Inclusion criteria were acute and traumatic wounds, sub-acute wounds, chronic open wounds (diabetic ulcers, pressure ulcers, venous stasis ulcers etc.) Exclusion criteria were fistulas of organs or body cavities, necrotic tissue in eschar, osteomylitis (untreated), malignancy in the wound, actively bleeding wounds. Data was collected by recording details of onset, duration, progress and wound characteristics along with demographic details in a prestructured proforma. Care was taken so that both the groups had a comparable distribution of patients with regards to age as well as etiology of the ulcer. The wounds were thoroughly debrided and the ulcer dimensions as well as the surface are assessed and depicted on the graphs before dressings were applied for both groups. Follow up of wound was done in all cases and wound assessed depending on wound size, wound bed score, percentage of granulation tissue cover on first and second week for both the wound dressings group. Wound characteristics were observed after second week with regard to the:

- Wound bed score and increase in wound bed score (Figure 1).

- Wound size and percentage of reduction of wound size.

- Percentage of granulation tissue cover.

- Percentages of graft take up.
Dressings were done one to four days apart for each patient depending on the amount of wound discharge for both the groups.

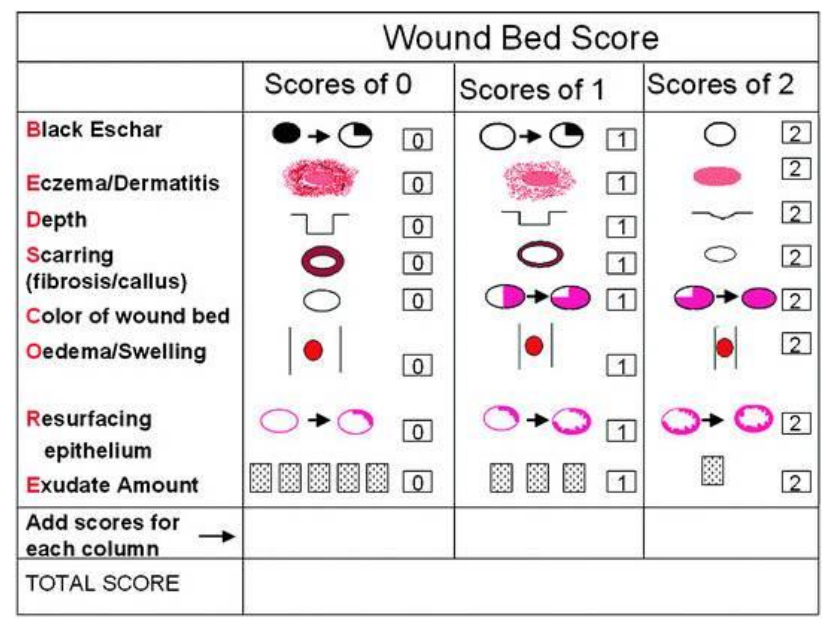

Figure 1: Wound bed score.

\section{Statistical analysis}

Unpaired students $\mathrm{T}$ test and paired $\mathrm{T}$ test were used to find out the statistical significance. A $\mathrm{P}$ value $<0.05$ was taken as significant. Technique of topical negative pressure dressing:

- A sterile polyurethane foam sponge dressing is cut to the approximate size of the wound and placed gently into position.

- A perforated drain tube is then placed on top of the foam and a second piece of foam placed over it.

- The foam, together with the first few inches of the drainage tube and the surrounding area of healthy skin, is then covered with the adhesive transparent membrane. At this stage it is important to ensure that the membrane forms a good seal both with the skin and the drainage tube.

- The distal end of the drain is connected to the device which provided a sub-atmospheric pressure at 125 $\mathrm{mmHg}$. This was achieved by wall suction apparatus or suction devices, suction was applied continuously or intermittently based on the amount of wound discharge.

- Once the vacuum is switched on, the air is sucked out of the foam causing it to collapse inwards drawing the edges of the wound in with it. STEP 6: Fluid within the wound is taken up by the foam and transported into the disposable container within the main vacuum unit (Figure 2). 


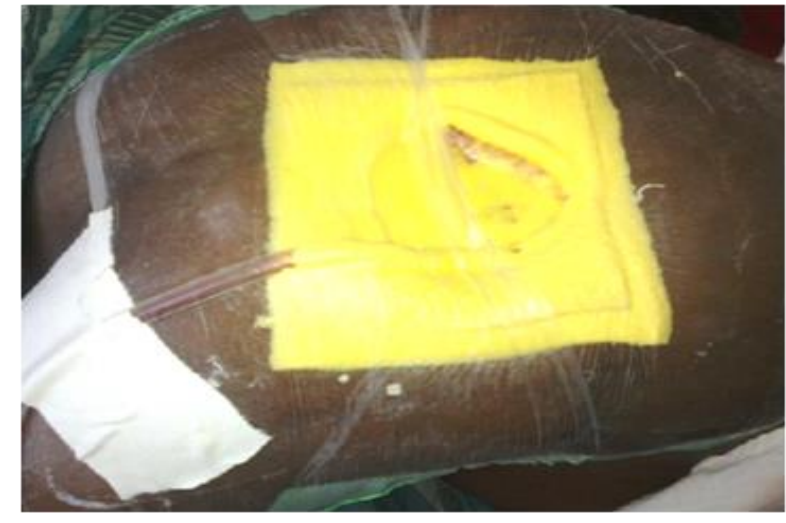

Figure 2: Topical negative pressure dressing applied to a wound.

\section{RESULTS}

The patient's characteristics of the two groups were comparable as elaborated in Table 1. In this study, the age of the patients ranged from 9 years to 75 years.

\section{Table 1: Comparative analysis of demographic characteristics in two groups.}

\begin{tabular}{|lll|}
\hline Characteristics & Study group & Control group \\
\hline Number of patients & 25 & 25 \\
\hline Age range in years & $9-70$ & $24-75$ \\
\hline $\begin{array}{l}\text { Sex ratio } \\
\text { (male:female) }\end{array}$ & $18: 7$ & $20: 5$ \\
\hline $\begin{array}{l}\text { Range of ulcer } \\
\text { surface area in square } \\
\text { centimetre }\end{array}$ & $16-234$ & $8-363$ \\
\hline
\end{tabular}

Of this 9-70 years were from study group and 24-75 years were from control group. $34 \%$ were in the age group of
51-60 years, of this $36 \%$ were in the study group and $32 \%$ were in the control group. Maximum number of cases $(64 \%)$ belonged to the age group of above 41 years. The mean age of study group was $43.56 \pm 17.94$ years and the mean age of control group was $49.60 \pm 14.90$ years. 28 $\%$ were females in the study group and $20 \%$ were females in control group. Etiology of the ulcer wise distribution in two groups is as depicted in Table 2.

In this study, $42 \%$ of the wounds were of diabetic etiology. The next most common wounds were post infective etiology at $32 \%$. The mean duration of number of days of hospital stay in the study group is $42.36 \pm 13.78$ and $46.76 \pm 28.36$ in the control group. The wound size at initial presentation in the study group is $107.07 \pm 87.23$ and in the control group is $89.19 \pm 81.72$, this is found to be statistically insignificant ( $p$ value $=0.2514$ ) thus implying the comparability of wound size at initial presentation.

Similarly the wound size after the completion of treatment in the study group is $89.79 \pm 81.73$ and in the control group is $82.99 \pm 73.71$ which is also found to be statistically insignificant $\mathrm{p}$ value $(\mathrm{p}$ value $=0.4822)$. The mean difference in wound size in the study group is $17.88 \pm 9.70$ and in control group is $6.79 \pm 9.09$,which shows, the difference is statistically highly significant ( $\mathrm{p}$ value $=0.0001$ ) indicating mean reduction in wound size in square centimeter for the study group is more than that of the control group (Table 3).

The wound bed score at initial presentation in the study group is 5.52 \pm 2.42 and in the control group is 5.08 \pm 1.44 , this is found to be statistically insignificant (p value $=0.4382$ ) thus implying the comparability of wound bed score at initial presentation.

Table 2: Etiological distribution of ulcers in two groups.

\begin{tabular}{|lllll|}
\hline Type of ulcer & Study group & Percentage & Control group & Percentage \\
\hline Diabetic ulcer & 7 & 28.00 & 14 & 56.00 \\
\hline Post infective raw area & 7 & 28.00 & 9 & 36.00 \\
\hline Traumatic ulcer & 9 & 36.00 & 2 & 8.00 \\
\hline Venous ulcer & 2 & 8.00 & 0 & 0.00 \\
\hline Total & 25 & 100.00 & 25 & 100.00 \\
\hline
\end{tabular}

Table 3: Wound size in square centimetre before and after treatment in study and control group.

\begin{tabular}{|c|c|c|c|c|c|c|}
\hline Treatment & Groups & $\mathbf{n}$ & Mean & Standard deviation & t-value & P-value \\
\hline \multirow{2}{*}{ Before } & Study group & 25 & 107.07 & 87.23 & \multirow{2}{*}{0.748} & \multirow{2}{*}{0.458} \\
\hline & Control group & 25 & 89.19 & 81.72 & & \\
\hline \multirow{2}{*}{ After } & Study group & 25 & 89.79 & 81.73 & \multirow{2}{*}{0.309} & \multirow{2}{*}{0.759} \\
\hline & Control group & 25 & 82.99 & 73.71 & & \\
\hline \multirow{2}{*}{ Difference } & Study group & 25 & 17.88 & 9.70 & \multirow{2}{*}{4.2085} & \multirow{2}{*}{$0 . .0001$} \\
\hline & Control group & 25 & 6.79 & 9.09 & & \\
\hline
\end{tabular}

* p-value $<0.05$ statistically significant. 
Similarly the wound bed score after the completion of the treatment in the study group is $15.12 \pm 1.54$ and in the control group is $10.20 \pm 2.69$ which is statistically significant. The mean difference in wound bed score in the study group is $9.60 \pm 2.16$ and the control group is $5.12 \pm 1.99$, the difference is statistically significant ( $\mathrm{p}$ value $=0.0001)($ Table 4).

Table 4: Wound bed score before and after treatment in study and control group.

\begin{tabular}{|c|c|c|c|c|c|c|}
\hline Treatment & Groups & $\mathbf{n}$ & Mean & Standard deviation & t-value & P-value \\
\hline \multirow{2}{*}{ Before } & Study group & 25 & 5.52 & 2.42 & \multirow{2}{*}{0.7817} & \multirow{2}{*}{0.4382} \\
\hline & Control group & 25 & 5.08 & 1.44 & & \\
\hline \multirow{2}{*}{ After } & Study group & 25 & 15.12 & 1.54 & \multirow{2}{*}{7.9355} & \multirow{2}{*}{$0.00001^{*}$} \\
\hline & Control group & 25 & 10.20 & 2.69 & & \\
\hline \multirow{2}{*}{ Difference } & Study group & 25 & 9.60 & 2.16 & \multirow{2}{*}{7.6339} & \multirow{2}{*}{$0 . .00001 *$} \\
\hline & Control group & 25 & 5.12 & 1.99 & & \\
\hline
\end{tabular}

$* \mathrm{p}$ - value $<0.05$ statistically significant

The percentage of granulation tissue formation in the study group is $81.0 \pm 8.29$ and in the control group is $53.60 \pm 19.23$, which is found to be statistically significant ( $p$ value $=0.00001$ ). The percentage of graft take up in the study group is $83.42 \pm 4.43$ and in the control group is $63.18 \pm 11.24$, which is found to be statistically significant ( $\mathrm{p}$ value $=0.00001$ )

\section{DISCUSSION}

The practice of exposing a wound to sub-atmospheric pressure for an extended period to promote debridement and healing was first described by Fleischmann et al in 1993. ${ }^{4}$ The original description of negative pressureassisted wound therapy was presented by Argenta and associates in 1997.5

Negative pressure may act by reducing edema, by removing interstitial fluid and by increasing the blood flow. ${ }^{6}$ Negative pressure induced mechanical shear stresses were able to activate the vascular endothelial cell growth factor (VEGF) pathway without any VEGF being present in the culture fluid. ${ }^{6,7}$ As a result, bacterial counts decrease and cell proliferation increases, thereby creating a suitable bed for graft or flap cover. Applying intermittent negative pressure of approximately $-125 \mathrm{mmHg}$ appears to hasten debridement and the formation of granulation tissue in chronic wounds and ulcers. ${ }^{8}$ Study by Labler, Ludwig MD et al in 2009 concluded that negative pressure therapy of traumatic wounds leads to increased local IL-8 and VEGF concentrations, which may trigger accumulation of neutrophils and angiogenesis and thus, accelerate neovascularization. ${ }^{9}$

Comparison of the present study with similar studies conducted by others shows, Tauro et al and Joseph et al have comparable mean age. Tauro et al has higher sample size of 56 than the present study, Joseph et al has lesser sample size of 18 as compared to present study i.e. $25 .^{10,11}$
Patients in our present study were suffering from ulcers of varied etiology, most common etiology was diabetic, next most common was infective etiology. In Tauro et al also the main etiology was diabetic ulcer but next most common cause was pressure ulcer and in our present study there was no ischemic ulcer and pressure ulcer. ${ }^{10}$

Prabhdeep SN et al, study in 15 diabetic foot ulcers, received vacuum dressing percentage of mean reduction of wound of $16.14 \%$ which is lesser compare to present study, and mean age is higher (61.33 years) compare to present study (43.56 years). ${ }^{12}$ Nather et al, done study of vacuum dressing in 5 diabetic foot ulcers, shows higher percentage of reduction in wound size (32.8\%) compare to present study $(25.57 \%){ }^{13}$

Present study has comparable granulation tissue cover of $81.00 \%$ for vacuum group and $54.66 \%$ for control group to Joseph et al, $81.56 \%$ in vacuum group and $54.30 \%$ in control group, Tauro et al has lesser granulation tissue cover $(71.43 \%)$ compare to present study. Present study has comparable percentage of graft take up $83.42 \%$ vacuum group and $63.18 \%$ control group with both studies. Tauro et al $79.29 \%$ in vacuum group, $60.45 \%$ in control group and Joseph et al $85.30 \%$ in vacuum group, $56.43 \%$ in control group. In present study split skin graft was done only in 19 patients in study group and 11 patients in control group. 10,11

There is significant increase in wound bed score in the

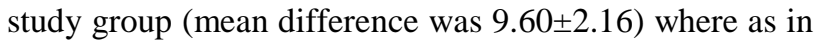
the control group there was not much increase in wound bed score (mean difference was 5.12 \pm 1.99 ) ( $\mathrm{p}$-valve 0.00001) which is statistically significant. Even the percentage of granulation tissue formation and the percentage of graft take up is higher in the study group compared to the control group, which is statistically significant ( $\mathrm{p}$ value <0.001) in both variables. Complications have been reported with topical negative pressure dressing such as toxic shock syndrome, retained sponge, bleeding in patients on anti - coagulation in our study we did not encounter any complications. ${ }^{14,15}$ 
Though the mean duration of hospital stay is statistically not significant, it is less in study group compare to control group. Number of dressings were less in the topical negative pressure dressing group hence reducing the cost of dressing when compared to conventional wound dressings group.

\section{CONCLUSION}

In our study it is concluded that wound bed score, the rate of granulation tissue formation, reduction in wound size, graft take up are better in the topical negative pressure dressing group when compared to the conventional wound dressing group. It was also seen that topical negative pressure dressing is cost effective and overall hospital stay is less in the topical negative pressure therapy. Hence vacuum dressing is proved to be more efficient than the normal saline dressing.

\section{ACKNOWLEDGEMENTS}

Author would like to thank SDM College of Medical Sciences, Sattur, Dharwad, India.

Funding: No funding sources Conflict of interest: None declared

Ethical approval: The study was approved by the institutional ethics committee

\section{REFERENCES}

1. Stephanie RG, Robert FD. Wound healing primer. Surg Clin N Am. 2010;90:1133-46.

2. Courtiey MT, Beauchamp RD, Markevers B, Kenneth L, Mattox S. Textbook of Surgery; The Biological Basis of Modern Surgical Practice: $19^{\text {th }}$ edition; Saunders;2012:151-177.

3. Brunicardi FC, Anderson DK, Billiar TR, Dunn DL, Hunter JG, Matthews JB et al. Schwartz's Principles of Surgery. $9^{\text {th }}$ editon. New York: Mc Graw Hill; 2009:210-234.

4. Fleischmann W, Strecker W, Bombelli M, Kinzl L. Vacuum sealing as treatment of soft tissue damage in open fractures. Unfallchirurg 1993;96(9):488-92.

5. Argenta LC, Morykwas MJ. Vacuum-assisted closure: a new method for wound control and treatment: clinical experience. Ann Plast Surg. 1997;38(6):563-76.

6. Michael J. Morykwas, Jordan S, Punger BS, Argenta BA, Kremers BSL. Vacuum-assisted closure: state of basic research and physiologic foundation. Plast Reconstr Surg. 2006;117(7 Suppl):121S-6S.

7. Chen KD, Li YS, Kim M. Mechano transduction in response to shear stress: roles of receptor tyrosine kinases, integrins, and Shc. J Biol Chem. 1999;274:18393.

8. Norman SW, Christopher JKB, O'Connell PR. Bailey and love's short practice of surgery; $26^{\text {th }}$ edition. Hodder Arnold; 2013:26.

9. Labler, Ludwig, Rancan, Mario, Mica, Ladislav, Harter, Luc. Vacuum-Assisted closure therapy increases local interleukin-8 and vascular endothelial growth factor levels in traumatic wounds. J Trauma Injur Infec Crit Care. 2009;66(3):749-57.

10. Tauro LF, Ravikrishnan J, Rao BSS, Shenoy HD, Shetty SR, Menezes LT. A comparative study of the efficacy of topical negative pressure moist dressings and conventional moist dressings in chronicwounds. Indian J Plastic Surg. 2013;40(2):133-40.

11. Joseph E, Hamori CA, Bergman S, Roaf E, Swann $\mathrm{NF}$, Anastasi GW. A prospective randomized trial of vacuum-assisted closure versus standard therapy of chronic nonhealing wounds. Wounds. 2000;2(3):60-76.

12. Prabhdeep SN, Sanjeev KU, Garg R. Role of negative pressure wound therapy in healing of diabetic foot ulcers. J Surg Tech Case Report. 2001:3(1);17-22.

13. Nather A, Yau H, Wong KL. Effectiveness of bridge VAC dressing in the treatment of diabetic foot ulcers. Diabetic Foot and Ankle. 2011;2:5893.

14. Gwan N, Casal RS. Toxic shock syndrome associated with the use of the vacuum-assisted closure device. Ann Plast Surg. 2001;47:552.

15. Argenta LC, Michael MD, Morykwas J, Malcolm W, Marks MD, Anthony J, et al. Vacuum-assisted closure: state of clinic art. Plast Reconstr Surg. 2006;117(7 Suppl):127S-42S.

Cite this article as: Koppad SN, Badiger S, Desai M, Kodliwadmath H. Comparative analysis of the efficacy of topical negative pressure dressing with conventional wound dressing in wound healing. Int Surg J 2016;3:1287-91. 